\title{
Recent Advances in Minimally Invasive Colorectal Cancer Surgery
}

\author{
M.W. Wichmann ${ }^{\mathrm{a}} \quad$ G. Meyer ${ }^{\mathrm{b}} \quad$ M.K. Angele ${ }^{\mathrm{a}, \mathrm{c}} \quad$ F.-W. Schildberg ${ }^{\mathrm{a}} \quad$ H.G. Rau \\ ${ }^{a}$ Department of Surgery, Klinikum Großhadern, Ludwig-Maximilians-Universität, München \\ ${ }^{b}$ Department of Surgery, Chirurgische Privatklinik Bogenhausen \\ c Department of Surgery, Amperkliniken Dachau
}

Key Words

Colorectal cancer · Laparoscopic surgery

\section{Summary}

Laparoscopy has improved surgical treatment of various diseases due to its limited surgical trauma and has developed as an interesting therapeutic alternative for the resection of colorectal cancer Despite numerous clinical advantages (faster recovery, less pain, fewer wound and systemic complications, faster return to work) the laparoscopic approach to colorectal cancer therapy has also resulted in unusual complications, i.e. ureteral and bladder injury which are rarely observed with open laparotomy. Moreover, pneumothorax, cardiac arrhythmia, impaired venous return, venous thrombosis as well as peripheral nerve injury have been associated with the increased intraabdominal pressure as well as patient's positioning during surgery. Furthermore, undetected small bowel injury caused by the grasping or cauterizing instruments may occur with laparoscopic surgery. In contrast to procedures performed for nonmalignant conditions, the benefits of laparoscopic resection of colorectal cancer must be weighed against the potential for poorer long-term outcomes of cancer patients that still has not been completely ruled out. In laparoscopic colorectal cancer surgery, several important cancer control issues still are being evaluated, i.e. the extent of lymph node dissection, tumor implantation at port sites, adequacy of intraperitoneal staging as well as the distance between tumor site and resection margins. For the time being it can be assumed that there is no significant difference in lymph node harvest between laparoscopic and open colorectal cancer surgery if oncological principles of resection are followed. As far as the issue of port site recurrence is concerned, it appears to be less prevalent than first thought (range $0-2.5 \%$ ), and the incidence apparently corresponds with wound recurrence rates observed after open procedures. Short-term (3-5 years) survival rates have been published by a number of investigators, and survival rates after laparoscopic surgery appears to compare well with data collected after conventional surgery for colorectal cancer. However, long-term results of prospective randomized trials are not available. The data published so far indicate that the oncological results of laparoscopic surgery compare well with the results of the conventional open approach. Nonetheless, the limited information available from prospective studies leads us to propose that minimally invasive surgery for colorectal cancer surgery should only be performed within prospective trials.
Schlüsselwörter

Kolorektales Karzinom · Laparoskopische Chirurgie

\section{Zusammenfassung}

Durch das reduzierte Zugangstrauma der laparoskopischen Operationsverfahren hat sich die Therapie einer Vielzahl von Erkrankungen verändert und diese Methode ist so auch zu einer interessanten therapeutischen Alternative beim kolorektalen Karzinom geworden. Trotz einer Vielzahl von klinischen Vorteilen (kürzere Rekonvaleszenz, geringere postoperative Schmerzen, weniger systemische und lokale Komplikationen, schnellere Wiedererlangung der Arbeitsfähigkeit), ist es durch den laparoskopischen Zugang auch zu einer Zunahme von bislang ungewohnten Komplikationen (z.B. Blasen- und Uretherverletzungen) gekommen. Weiterhin wurde eine höhere Inzidenz von Pneumothoraces, Herzrhythmusstörungen, Venenthrombosen und peripheren Nervenverletzungen aufgrund des perioperativ erhöhten intraabdominellen Drucks beobachtet. Darüber hinaus besteht die Gefahr von unbemerkten Dünndarmverletzungen, die intraoperativ durch Greif- bzw. Koagulationsinstrumente verursacht werden können. Im Gegensatz zu Operationen, die wegen gutartiger Erkrankungen durchgeführt werden, müssen die Vorteile der laparoskopischen Chirurgie bei malignen Erkrankungen gegen die potentiell schlechteren onkologischen Langzeitergebnisse abgewogen werden, welche bislang noch nicht endgültig ausgeschlossen werden konnten. Diesbezüglich gibt es wesentliche onkologische Kriterien, die sich bei der laparoskopischen Chirurgie noch in der Evaluation befinden. Hierzu zählen unter anderem das Ausmaß der Lymphknotendissektion, die Frage der Tumorzellimplantation im Bereich der Trokarinzisionen, die Qualität des intraoperativen Tumor-Stagings sowie das Ausmaß der Sicherheitsabstände. Die bislang vorliegenden Ergebnisse deuten darauf hin, dass keine signifikanten Unterschiede zwischen konventioneller und laparoskopischer Chirurgie bezüglich dieser onkologischen Kriterien bestehen, wenn die allgemein gültigen Prinzipien der onkologischen Chirurgie befolgt werden. Insbesondere das Auftreten von Trokarmetastasen (Inzidenz 0-2,5\%) scheint nicht so häufig zu sein, wie initial befürchtet, und entspricht der Rate von Metastasen im Bereich der Laparotomienarbe nach konventioneller Operation. Die Kurzzeit-Überlebensraten (3-5 Jahre), die von einigen Arbeitsgruppen vorgelegt wurden, zeigen keine signifikanten Nachteile für $\mathrm{Pa}-$ tienten nach laparoskopischer Chirurgie gegenüber konventionell operierten Patienten. Langzeit-Ergebnisse von prospektiv randomisierten Studien liegen allerdings noch nicht vor. Die bislang verfügbaren Daten deuten darauf hin, dass die onkologischen Ergebnisse der laparoskopischen Chirurgie beim kolorektalen Karzinom mit den Ergebnissen der konventionellen Chirurgie vergleichbar sind. Aufgrund der bislang unzureichenden Datenlage aus prospektiv randomisierten Studien halten wir den Einsatz der minimal invasiven Chirurgie beim kolorektalen Karzinom nur im Rahmen von prospektiven Studien für gerechtfertigt.

\begin{tabular}{ll}
\hline KARGER & @ 2002 S. Karger GmbH, Freiburg \\
Fax +497614520714 & Accessible online at: \\
$\begin{array}{l}\text { E-mail Information@Karger.de } \\
\text { www.karger.com }\end{array}$ & www.karger.com/journals/onk
\end{tabular}

Prof. Dr. med. Horst Günther Rau

Department of Surgery, Amperkliniken Dachau

Krankenhausstraße 15, D-85221 Dachau (Germany)

Tel. +49 8131 76-366, Fax -47 75

E-mail horst-guenter.rau@amperkliniken.de 


\section{Introduction}

Laparoscopy has improved surgical treatment of various diseases due to its limited surgical trauma [1]. During recent years the laparoscopic approach therefore has developed as an interesting therapeutic alternative for the resection of colorectal cancer. This procedure has been shown to be feasible in most patients with benign disease and can be performed without an increase of perioperative morbidity and mortality rates [2-5]. The laparoscopic approach usually allows for a rapid return to preoperative activity levels with significantly shorter hospitalization, and a recent report indicates reduced rates of postoperative ileus, wound infection and cardiorespiratory complications after laparoscopic surgery when compared with the open approach [6].

Experimental and clinical data suggest that laparoscopic surgery is also suitable for the treatment of malignant disease, and it appears that laparoscopic resection of colorectal cancer is associated with clinically relevant benefits during the first weeks after surgery and that it can be performed with the same intention of radical treatment as conventional resection [7]. A recent study, however, reported that only minimal short-term quality of life benefits could be observed with laparoscopically assisted colectomy when compared with open colectomy for colon cancer [8]. These authors therefore concluded that laparoscopic colectomy should only be performed within prospective trials to evaluate the oncological safety of this surgical approach [8] as it has also been suggested by the American Society of Colon and Rectal Surgeons [9]. The data published so far, nonetheless, indicate that the oncological results of laparoscopic surgery compare well with the results of the conventional open approach [10-15]. Until now, the available trials assessing the value of laparoscopy in colorectal cancer, however, lacked sufficient statistical power due to small numbers of patients or had short follow-up periods which did not allow proper evaluation of the oncological safety [1]. Thus, despite the observed clinical advances of the minor access approach, the role of minimal invasive procedures in oncological surgery is not yet defined [16].

We discuss herein the established procedures of minimally invasive surgery for colorectal disease as well as the current role of laparoscopic surgery for colorectal carcinoma with special attention to surgical safety (length of surgery, blood loss, perioperative morbidity, and mortality rates) as well as the oncological results (number of harvested lymph nodes, length of security margins, long-term survival). Furthermore, we address the immunological effects of laparoscopic versus conventional colorectal surgery.

\section{Established Minimally Invasive Surgical Procedures for Colorectal Disease}

In 1997, Herold et al. [17] reported that only $15 \%$ of all surgical departments in Germany had experience with laparoscop- ic colorectal operations. Furthermore, these authors showed that only $1 \%$ of all cases $(n=143,000)$ underwent laparoscopic surgery [17] which has also been reported by Köckerling et al. [5]. Even though no recent study addresses the interesting clinical question of how many laparoscopic colorectal procedures are being performed when compared with the total number of cases undergoing surgery for colorectal diseases, it appears that minimal invasive colorectal surgery is gaining more and more attention and is being performed in a number of surgical departments.

The current role of laparoscopic surgery in colorectal cancer can be divided into three categories: diagnosis and staging, palliation and diversion as well as curative resection [18]. Tittel and Schumpelick [19] showed that the most frequently performed laparoscopic colorectal procedures are resections of the sigmoid colon (30\%), anterior rectal resections $(31 \%)$ as well as resections of the ascending colon (20\%). The study by Köckerling et al. [5], however, revealed that laparoscopic procedures are more common on the left colon and rectum than on the right colon. In our institution the minimal invasive approach was most commonly used for the rectum (70\%) and the majority of these interventions were anterior resections (54\%) for benign as well as malignant diseases.

Laparoscopic surgery of the transverse colon is technically demanding due to the position of the greater omentum and can be impossible due to anatomical problems (e.g. elongation of the transverse colon). Only limited experience with laparoscopic surgery on the descending colon $(3.5 \%)$ has been reported in the literature [19]. This is surprising since mobilization of the left colon is necessary for a tension-free anastomosis after anterior rectal resections and, therefore, is feasible in the clinical setting.

As far as the technique of total mesorectal excision (TME) for low rectal cancer is concerned, it has been shown by Weiser and Milsom [20] in a human cadaver model as well as in a clinical study that TME can be performed via the minimally invasive approach. This observation has been recently confirmed by Hartley et al. [21]. In our institution, laparoscopic TME is routinely performed in patients suffering from rectal cancer. It appears that the surgical site as well as the resection planes are easier to evaluate and to dissect by the laparoscopic approach than via conventional open surgery. This clinical experience, however, still lacks support by results from prospective clinical studies.

\section{Surgical Safety}

Advances in the development of laparoscopic instruments allow for the safe resection of polyps or malignant disease. Until now, T1, T2 and T3 lesions can be resected using the laparoscopic approach while $\mathrm{T} 4$ tumors require conversion to open laparotomy for en bloc resection of the affected organs [13]. 
The laparoscopic approach to colorectal cancer therapy has resulted in unusual complications, i.e. ureteral and bladder injury which are rarely observed with open laparotomy [13]. Larach and Gallagher [22] recently reviewed possible complications of laparoscopic surgery for rectal cancer. According to these authors, gas embolism appears to be a rare complication which is usually associated with the placement of a Veress needle directly into a vein [22]. As opposed to Larach and Gallagher [22] who recommend not to use the Veress needle for installation of the pneumoperitoneum, Hüttl et al. [23] showed that most surgeons in Germany (70\%) still apply this method for placement of the initial port. In addition to the above-mentioned perioperative complications, pneumothorax, cardiac arrhythmia, impaired venous return, venous thrombosis as well as peripheral nerve injury have been associated with the increased intraabdominal pressure as well as patient's positioning during surgery [22]. Furthermore, undetected small bowel injury caused by the grasping or cauterizing instruments may occur more often with laparoscopic surgery (range $0.2-5 \%$ ) than during conventional open procedures $[13,22]$. Uncontrolled bleeding and major hemorrhage during laparoscopic surgery result from blunt dissection or incorrect clip and stapler placement. These complications require rapid conversion to open laparotomy if the anatomy becomes unclear or the bleeding source cannot be controlled [22].

According to Köckerling et al. [5], laparoscopic colorectal procedures can be performed with a postoperative mortality rate of less than $2 \%$ in a selected patient group. The overall morbidity rate in the study by Köckerling and colleagues was $21 \%$, and the clinical anastomotic leakage rate was 5\% [5]

A recent randomized trial compares the short-term qualityof-life outcomes after laparoscopically assisted colectomy with those of open colectomy for colon cancer in 428 patients [8]. The authors reported a statistically significant but clinically modest decrease in the duration of postoperative inhospital analgesia and in length of stay ( 0.8 days) for patients after laparoscopic resection [8]. These differences, however, did not translate into statistically significant improvements in symptoms or quality of life during the immediate postoperative or the 2-month follow-up period [8].

In our institution, mean length of laparoscopic colorectal surgery was $229 \pm 13 \mathrm{~min}$, and the mean intraoperative blood loss was $290 \pm 36 \mathrm{ml}$, requiring blood transfusion in $6 \%$ of our patients. Perioperative mortality and morbidity rates were 0 and $31 \%$, respectively. A revision due to postoperative complications became necessary in $11 \%$ of our patients.

\section{Oncological Safety}

When performing laparoscopic colorectal cancer surgery, there are important cancer control issues to be checked. These include the extent of lymph node dissection, tumor implanta- tion at port sites, adequacy of intraperitoneal staging as well as the distance between tumor site and resection margins.

Although a number of studies have shown that the extent of laparoscopic curative resection of bowel and lymphatic tissue is comparable to that with open surgery [10-14, 24, 25], laparoscopic surgery for the cure of colorectal cancer remains controversial. In contrast to procedures performed for nonmalignant conditions, the benefits of laparoscopic resection of colorectal cancer must be weighed against the potential for poorer long-term outcomes of cancer patients that still has not been completely ruled out. Poorer long-term results may be due to inadequate resections, port site recurrences, or unusual spread of metastases after laparoscopic surgery for malignant disease [8].

The identification of the tumor site as well as possible additional lesions may be difficult during laparoscopic colorectal surgery. Preoperative colonoscopy therefore is mandatory to avoid the missing of additional lesions which can be detected in almost $5 \%$ of patients with colorectal cancer [26, 27].

The fear of port site recurrence is the leading concern for laparoscopic colorectal cancer resection. However, initial reports of an incidence of trocar metastases as high as $20 \%$ appear to be attributable to the individual surgical technique [28]. This phenomenon is less prevalent than first thought (range $0-2.5 \%$ ) and appears to correspond with wound recurrence rates observed after open procedures $[1,13]$. Welch and Donaldson [29], however, reported an incidence of almost $17 \%$ laparotomy recurrences identified at autopsy after open resection of colorectal cancer.

The study by Sugarbaker and Corlew [30] support the notion that an extended regional lymph node dissection does not appear to improve survival when compared with a regional dissection. Despite this observation, it is our believe - which is also supported by others [31a] - that significant prognostic information is based on resected lymph nodes [31b]. As far as the published results of lymph node harvest are concerned, Lin and Ota [13] recently showed that the mean number of resected lymph nodes during laparoscopic colorectal cancer surgery varied between 6 and 19 nodes per resected specimen in 21 different studies published between 1993 and 2000. For the time being it can be assumed that there is no significant difference in lymph node harvest between laparoscopic and open colorectal cancer surgery if oncological principles of resection are followed [13].

In our institution, a mean number of $14 \pm 1$ lymph nodes was detected within the cancer-bearing specimen after laparoscopic surgery while after open surgery $19 \pm 1$ lymph nodes $(\mathrm{p}<$ $0.05)$ were available for pathological evaluation. The clinical relevance of this observation still remains to be determined. Our findings, however, indicate that during laparoscopic surgery for colorectal cancer the principles of oncological resections must be followed with great care in order to harvest a sufficient number of lymph nodes. The mean lengths of security margins measured in the specimens resected in our depart- 


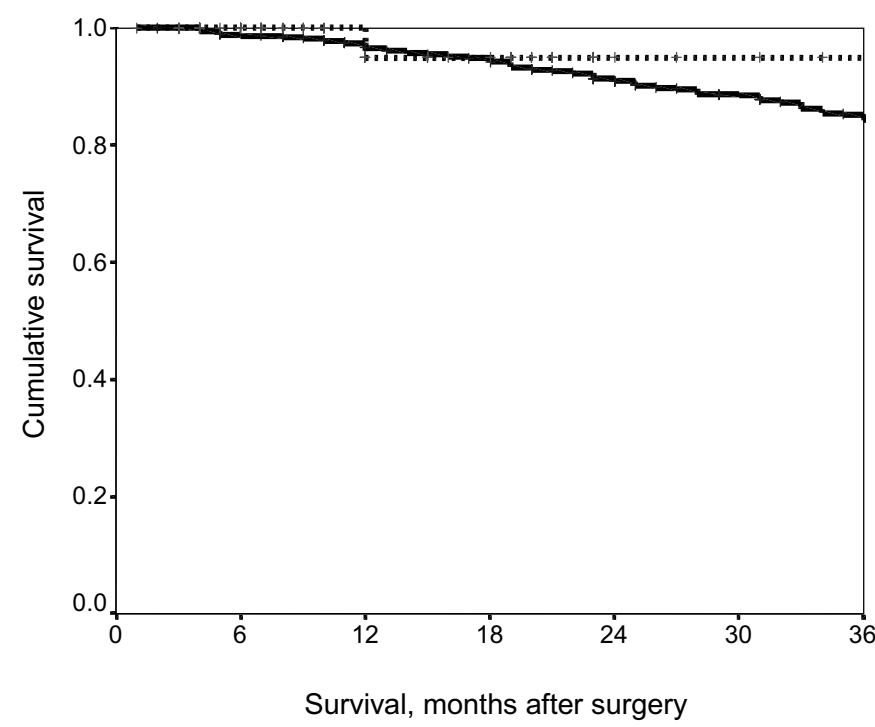

Fig. 1. Three-year survival rates after open surgery for rectal cancer (— — $\mathrm{n}=477$ patients) and after laparoscopic rectal cancer resection $(\cdots+\cdots ; \mathrm{n}=65$ patients $) . \log$ rank $=0.8112$.

ment during laparoscopic surgery were $13 \pm 1 \mathrm{~cm}$ orally and 4 $\pm 1 \mathrm{~cm}$ distally. The circumferential resection margin has recently become of special interest since Birbeck et al. [32] have shown that infiltration of the circumferential margin or cancer infiltration below $1 \mathrm{~mm}$ to the circumferential margin is an immediate predictor of survival and serves as a useful indicator of surgical quality. The circumferential resection margin after minimally invasive surgery for colorectal cancer was $3 \pm 1 \mathrm{~cm}$ in our department. The observations from our department support the notion that sufficient security margins can be achieved with laparoscopic surgery for malignant disease. This was also reported by other groups [10-14, 24, 25]. Until now, only limited survival data are available in our institution. The achieved 3-year survival rates, however, are comparable with the survival rates of our patients after conventional open surgery for colorectal cancer (fig. 1 ; log rank $=0.8112$ ). Comparable short-term (3-5 years) survival rates were also reported by Fleshman et al. [33], Schwandner et al. [14] as well as Leung et al. [34]. Long-term results of prospective randomized trials are not available despite these promising findings.

\section{Immunological Effects}

Minimizing surgical trauma due to a smaller access to the surgical site might have beneficial effects on the postoperative immune status of the individual patient. This could contribute to fewer infectious complications, faster recovery as well as better killing of circulating tumor cells in cancer patients.

Despite numerous publications addressing this interesting clinical issue, there is no scientific evidence-based answer to the question of whether or not the above-mentioned hypothe-

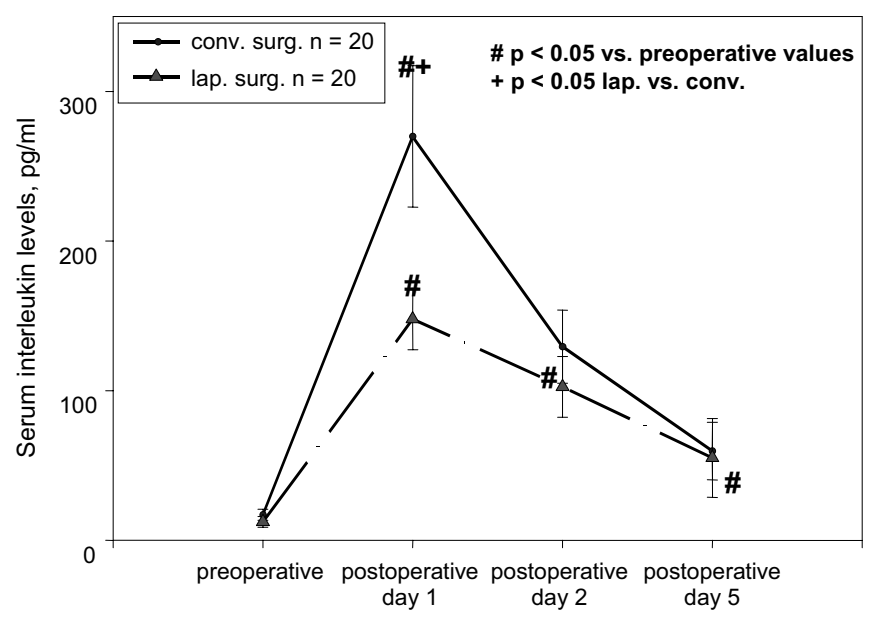

Fig. 2. Serum interleukin-6 levels as determined by ELISA (Biosource, Camarillo, CA, USA) in patients after laparoscopic (lap.; $\mathrm{n}=20$ ) and conventional (conv.; $\mathrm{n}=20$ ) colorectal surgery (surg.).

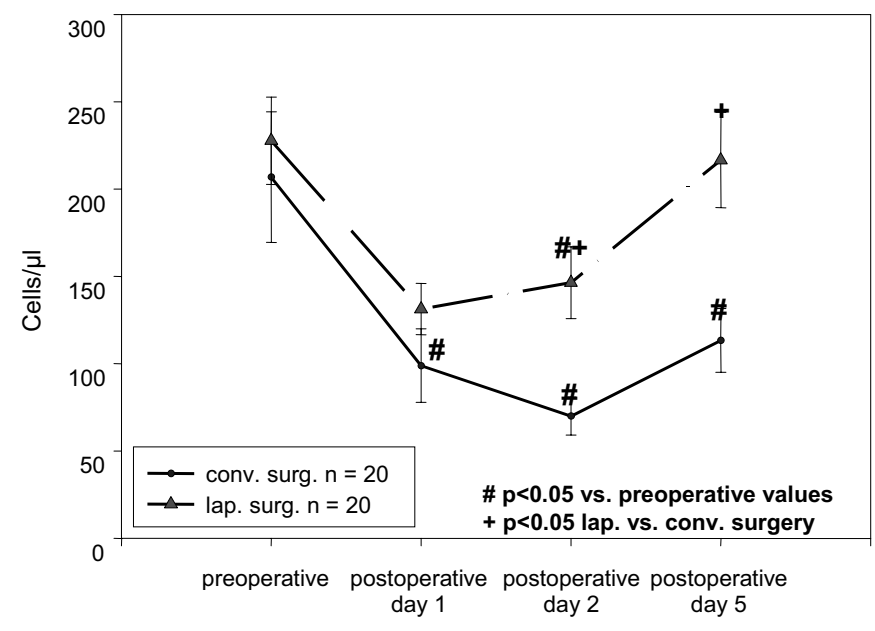

Fig. 3. Circulating natural killer cells [CD3-, CD16/56+] as determined by flow cytometry (FACScan, Becton Dickinson, Heidelberg, Germany) in patients after laparoscopic $(n=20)$ and conventional $(n=20)$ colorectal surgery.

sis on the advantages of minimal access surgery holds true. Nonetheless, the degree of postoperative inflammation seems to be lower after laparoscopic surgery [16]. Furthermore, there is no doubt that far less impairment of lung function occurs after minimal invasive surgery [16]. Moreover, less postoperative pain, shorter duration of hospitalization, and faster recovery have been observed after laparoscopic colorectal cancer surgery when compared with the conventional approach $[16,35]$. The observed advantages in quality of life however level out in the course of time [8]. Until now, only few prospective clinical studies were published that compare the immunological response to laparoscopic with that to conventional surgery for colorectal cancer. Nonetheless, IL-6 and C-reactive protein levels were reported to be lower after la- 
paroscopic rectosigmoid resections [16]. This observation was also confirmed in a recent pilot study in our institution. After laparoscopic colorectal surgery, we observed a significantly smaller peak of serum IL-6 levels (fig. 2). Schwenk et al. [36] also observed significantly lower IL-6 and CRP plasma levels after laparoscopic than after conventional colorectal resections while IL-1RA and IL-10 levels showed no significant differences between both study groups. Moreover, the evaluation of the immune status after laparoscopic and conventional colorectal surgery by flow cytometry revealed significantly higher numbers of circulating natural killer cells in patients after minimal invasive colorectal resection (fig. 3). Other groups also observed significantly better preservation of lymphocyte subpopulations, neutrophil function as well as cell-mediated immunity after laparoscopic versus open colorectal surgery [37-39]. The data published so far support the notion that laparoscopic colorectal surgery may not be as detrimental for the postoperative immune status of patients undergoing colorectal cancer surgery. Prospective randomized immunological studies, however, are not available to evaluate whether or not these findings are of clinical and oncological relevance. The immunological role of minimally invasive surgery in oncological surgery therefore is not completely determined.

\section{Discussion}

The first report on laparoscopic colorectal interventions was published by Jacobs et al. [40] in 1991. Since then a rapid progress has been made in this field of minimally invasive surgery. Colorectal resections, nonetheless, still are among the most challenging current applications of laparoscopic surgery, and the demand on surgeons to acquire these advanced skills is increasing [41].

Optimal patient care and treatment-regimens for colorectal cancer patients remain controversial, and despite major efforts the 5-year-survival rate may be as low as 50\% [42, 43]. In order to improve these unfortunate survival rates, different protocols of preoperative radiochemotherapy as well as surgical procedures have been introduced $[44,45]$. Among the surgical procedures laparoscopy has become an interesting therapeutic alternative for the resection of colorectal cancer. Until now, laparoscopic colorectal surgery has been performed without an increase of perioperative morbidity and mortality rates $[2,3]$. After laparoscopic surgery a rapid return to preoperative activity levels with significantly shorter hospitalization has been observed, and reduced rates of postoperative ileus, wound infection and cardiorespiratory complications were reported [6]. Nonetheless, a recent report by Weeks et al. [46] indicated only minor advantages for patients undergoing laparoscopic colon cancer surgery. These authors concluded that laparoscopic surgery should not be offered to colon cancer patients until ongoing trials establish that laparoscopy is as effective as open surgery in preventing recurrence and death from colon cancer [46]. Additional studies, however, indicated that the oncologic results of laparoscopic surgery compare well with the results of the conventional open approach [10-12].

Laparoscopic colorectal cancer resection is feasible, but in view of the ongoing discussion about the oncological safety of this approach $[10-12,46]$, it should only be performed within clinical studies and in surgical centers that have sufficient experience with laparoscopic colorectal surgery for benign diseases.

\section{References}

1 The COLOR Study Group: COLOR: A randomized clinical trial comparing laparoscopic and open resection for colon cancer. Dig Surg 2000;17:617622.

2 Seow-Choen F, Eu KW, Ho YH, Leong AFPK: A preliminary comparison of a consecutive series of open versus laparoscopic abdomino-perineal resection for rectal adenocarcinoma. Int J Colorect Dis 1997;12:88-90.

3 Wexner SD, Reissman P, Pfeifer J, Bernstein M, Geron N: Laparoscopic colorectal surgery. Surg Endosc 1996;10:133-136.

4 Köckerling F, Rose J, Schneider C, Scheidbach H, Scheuerlein H, Reymond MA, Reck T, Konradt J, Bruch HP, Zornig C, Barlehner E, Kuthe A, Szinicz G, Richter HA, Hohenberger W: Laparoscopic colorectal anastomosis: Risk of postoperative leakage. Results of a multicenter study. Laparoscopic Colorectal Surgery Study Group (LCSSG). Surg Endosc 1999;13:639-644.

5 Köckerling F, Schneider C, Reymond MA, Scheidbach H, Konradt J, Barlehner E, Bruch HP, Kuthe A, Troidl H, Hohenberger W, for the Laparoscopic Colorectal Surgery Study Group (LCSSG): Early results of a prospective multicenter study on 500 consecutive cases of laparoscopic colorectal surgery. Surg Endosc 1998;12:37-41.
6 Stewart BT, Stitz RW, Lumley JW: Laparoscopically assisted colorectal surgery in the elderly. Br J Surg 1999;86:938-941.

7 Müller JM, Schwenk W, Jacobi CA, Böhm B: Endoscopic surgery: fit for malignancy? World J Surg 1999;23:808-815.

8 Weeks JC, Nelson H, Gelber S, Sargent D, Schroeder G: Short-term quality-of-life outcomes following laparoscopic-assisted colectomy vs open colectomy for colon cancer. A randomized trial. JAMA 2002;287:321-328.

9 American Society of Colonand Rectal Surgeons: Approved statement on laparoscopic colectomy. Dis Colon Rectum 1994;37:8-12.

10 Fleshman JW, Wexner SD, Anvari M, LaTulippe JF, Birnbaum EH, Kodner IJ, Read TE, Nogueras JJ, Weiss EG: Laparoscopic vs. open abdominoperineal resection for cancer. Dis Colon Rectum 1999;42:930-939.

11 Hoffman GC, Baker JW, Doxey JB, Hubbard GW, Ruffin WK, Wishner JA: Minimally invasive surgery for colorectal cancer. Initial follow-up. Ann Surg 1996;223:790-798.
12 Leung KL, Kwok SPY, Lau WY, Meng WCS, Lam TY, Kwong KH, Chung CC, Li AKC: Laparoscopic-assisted resection of rectosigmoid carcinoma. Immediate and medium-term results. Arch Surg 1997;132:761-764.

13 Lin KM, Ota DM. Laparoscopic colectomy for cancer: An oncologic feasible option. Surg Oncol 2000;9:127-134.

14 Schwandner O, Schiedeck TH, Killaitis C, Bruch HP: A case-control-study comparing laparoscopic versus open surgery for rectosigmoidal and rectal cancer. Int J Colorectal Dis 1999;14:158-163.

15 Milsom JW, Bohm B, Hammerhofer KA, Fazio V, Steiger E, Elson P: A prospective, randomized trial comparing laparoscopic versus conventional techniques in colorectal cancer surgery: A preliminary report. J Am Coll Surg 1998;187:46-54.

16 Feussner H, Siewert JR: Reduktion des Zugangstraumas: Gesicherte Vorteile. Chirurg 2001;72:236244.

17 Herold A, Shekarriz H, Casper L, Schiedeck T: Current status of laparoscopic colorectal surgery a nationwide survey. Langenbecks Arch Chir Suppl Kongressbd 1997;114:1185-1187. 
18 Tomita H, Marcello PW, Milsom JW: Laparoscopic surgery of the colon and rectum. World J Surg 1999;23:397-405.

19 Tittel A, Schumpelick V: Laparoscopic surgery: Expectation and reality. Chirurg 2001;72:227-235

20 Weiser MR, Milsom JW: Laparoscopic total mesorectal excision with autonomic nerve preservation. Semin Surg Oncol 2000;19:396-403.

21 Hartley JE, Mehigan BJ, Qureshi AE, Duthie GS, Lee PW, Monson JR: Total mesorectal excision Assessment of the laparoscopic approach. Dis Colon Rectum 2001;44:315-321.

22 Larach SW, Gallagher JT: Complications of laparoscopic surgery for rectal cancer: Avoidance and management. Semin Surg Oncol 2000;18:265-268.

23 Hüttl TP, Hohle M, Meyer G: Antirefluxchirurgie in Deutschland - Ergebnisse einer repräsentativen Umfrage mit Analyse von 2540 Antirefluxoperationen. Chirurg 2002;73:451-461.

24 Fleshman JW, Nelson H, Peters WR, Kim HC, Larach S, Boorse RR, Ambroze W, Leggett P, Bleday R, Stryker S, Christenson B, Wexner S, Senagore A, Rattner D, Sutton J, Fine AP: Early results of laparoscopic surgery for colorectal cancer. Retrospective analysis of 372 patients treated by Clinical Outcomes of Surgical Therapy (COST) Study Group. Dis Colon Rectum 1996;39:S53-S58.

25 Lord SA, Larach SW, Ferrara A, Williamson PR, Lago C-P, Lube MW: Laparoscopic resections for colorectal carcinoma. A three-year experience. Dis Colon Rectum 1996:39:148-154.

26 Finan PJ, Ritchie JK, Hawley PR: Synchronous and 'early' metachronous carcinomas of the colon and rectum. Br J Surg 1987;74:945-947.

27 Langevin JM, Nivatvongs S: The true incidence of synchronous cancer of the large bowel. A prospective study. Am J Surg 1984;147:330-333.

28 Müller JM, Schwenk W, Jacobi CA, Böhm B: Endoscopic surgery: Fit for malignancy? World J Surg 1999;23:808-815.

29 Welch JP, Donaldson GA: The clinical correlation of an autopsy study of recurrent colorectal cancer. Ann Surg 1979;189:496-502.
30 Sugarbaker PH, Corlew S: Influence of surgical techniques on survival in patients with colorectal cancer. Dis Colon Rectum 1982;25:545-557.

31a Cady B: Lymph node metastasis: Indicators but not governors of survival. Arch Surg 1984;119: 1067-1072.

31b Wichmann MW, Muller C, Meyer G, Strauss T, Hornung HM, Lau-Werner U, Angele MK, Schildberg FW: Effect of preoperative radiochemotherapy on lymph node retrieval after resection of rectal cancer. Arch Surg 2002;137:206-210.

32 Birbeck KF, Macklin CP, Tiffin NJ, Parsons W, Dixon MF, Mapstone NP, Abbott CR, Scott N, Finan PJ, Johnston D, Quirke P: Rates of circumferential resection margin involvement vary between surgeons and predict outcomes in rectal cancer surgery. Ann Surg 2002;235:449-457.

33 Fleshman JW, Wexner SD, Anvari M, LaTulippe JF, Birnbaum EH, Kodner IJ, Read TE, Nogueras JJ, Weiss EG: Laparoscopic vs. open abdominoperineal resection for cancer. Dis Colon Rectum 1999;42: 930-939.

34 Leung KL, Kwok SPY, Lau WY, Meng WCS, Lam TY, Kwong KH, Chung CC, Li AKC: Laparoscopic-assisted resection of rectosigmoid carcinoma. Immediate and medium-term results. Arch Surg 1997;132:761-764

35 Schwenk W, Böhm B, Müller JM: Postoperative pain and fatigue after laparoscopic or conventional colorectal resections. A prospective randomized trial. Surg Endosc 1998;12:1131-1136.

36 Schwenk W, Jacobi C, Mansmann U, Bohm B, Muller JM: Inflammatory response after laparoscopic and conventional colorectal resecti ons - results of a prospective randomized trial. Langenbecks Arch Surg 2000;385:2-9.

37 Kehlet H, Nielsen HJ: Impact of laparoscopic surgery on stress responses, immunofunction, and risk of infectious complications. New Horiz 1998;6: S80-S88.
38 Bessler M, Whelan RL, Halverson A, Treat MR, Nowygrod R: Is immune function better preserved after laparoscopic versus open colon resection? Surg Endosc 1994;8:881-883.

39 Carey PD, Wakefield CH, Thayeb A, Monson JRT, Darzi A, Guillou PJ: Effects of minimally invasive surgery on hypochlorous acid production by neutrophils. Br J Surg 1994;81:557-560.

40 Jacobs M, Verdaja JC, Goldstein HS: Minimally invasive colon resection (laparoscopic colostomy) Surg Laparoscop Endosc 1991;1:144-150.

41 Schlachta CM, Mamazza J, Seshadri PA, Cadeddu M, Poulin EC: Determinants of outcomes in laparoscopic colorectal surgery: A multiple regression analysis of 416 resections. Surg Endosc 2000;14: 258-263.

42 Read TE, McNevin MS, Gross EKM, Whiteford HM, Lewis JL, Ratkin G, Picus J, Birnbaum EH, Fleshman JW, Kodner IJ, Myerson RJ: Neoadjuvant therapy for adenocarcinoma of the rectum: Tumor response and acute toxicity. Dis Colon Rectum 2001;44:513-522.

43 Cohen AM, Minsky BD, Schilsky RL: Cancer of the colon; in DeVita VT Jr, Hellman S, Rosenberg SA (eds): Cancer: Principles and Practice of Oncology. Philadelphia, Lippincott-Raven, 1997, pp 1145-1197.

44 Wannenmacher M, Herfarth C: Belegtes zur präoperativen Therapie des Rectumcarcinoms. Chirurg 2000;71:1440-1446.

45 Havenga K, Enker WE, Norstein J, Moriya Y, Heald RJ, van Houwelingen $\mathrm{HC}$, van de Velde CJH: Improved survival and local control after total mesorectal excision or D3 lymphadenectomy in the treatment of primary rectal cancer: An international analysis of 1,411 patients. Eur J Surg Oncol 1999;25:368-374.

46 Weeks JC, Nelson H, Gelber S, Sargent D, Schroeder G: Short-term quality-of-life outcomes following laparoscopic-assisted colectomy vs open colectomy for colon cancer. A randomized trial. JAMA 2002;287:321-328 